\title{
Vergifnisonderwys: Die sleutel tot die ontlonting van ongelukkigheid oor sosiale onreg
}

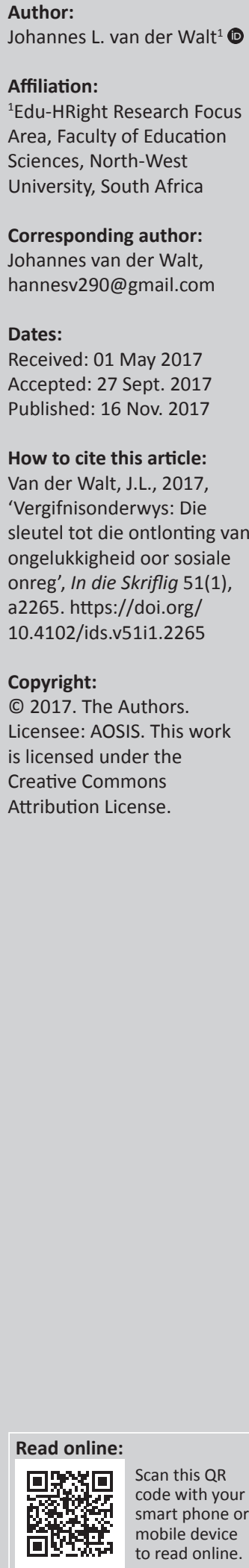

Forgiveness education: The key to the dissipation of misery due to social injustice. Personal and global conditions have recently highlighted the importance for individuals and communities to be able to forgive other individuals and communities for a variety of transgressions. Social injustice has often been perpetrated also in educational context as can be illustrated with reference to South Africa, the Baltic and the Balkan where these countries are still struggling today with the heritages of respectively their apartheid and communist past. History abounds with such incidences. Although some people and communities are able to spontaneously and intuitively forgive those who have inflicted social injustice upon them, most of us do not possess a complete grasp of what it means to forgive, what the fruits of a forgiving attitude could be or what the results of a non-forgiving attitude might be. In view of this, it has become necessary to resort to education (e.g. in the shape of citizenship education) to teach young people (how) to forgive and thereby helping them contribute to a peaceful democratic society. The article concludes with a Scriptural view of forgiveness and forgiveness education.

\section{Inleiding en probleemstelling}

Nagenoeg alle mense beleef van tyd tot tyd die een of ander vorm van sosiale onreg (onder meer in die vorm van diskriminasie, minagting, bedrog en leuens, onenigheid) as gevolg van drank- of dwelmmisbruik, uitbuiting, misdaad en dies meer. Die probleem van sosiale onreg wat mense aangedoen word, het in die afgelope tyd vererger deur omstandighede meegebring deur globalisering, migrasie en sosiale transformasieprosesse. Hierdie verwikkelings is medeverantwoordelik vir die toename in vooroordeel tussen individue (insluitend skoolkinders) en gemeenskappe (Rieker 2004:5). Wahl (2004:11-17) meen dat pyn en smart dikwels deur die volgende faktore veroorsaak word: ekstremistiese en onverdraagsame gedrag waardeur die ander as minderwaardig en ongelyk gesien word, deur on- of asosiale gedrag, deur anargie, haat, nyd, aggressie, woede, opvlieëndheid, oorheersing van ander, kinders wat sleg behandel word deur ouers en onderwysers, uitlokking, afwykende gedrag, 'n gebrek aan empatie met andere, asook stigmatisering, afknouery en stereotipering. Diegene wat onder hierdie gedrag deurloop, openbaar allerlei moeilik hanteerbare vorms van gedrag, byvoorbeeld minderwaardigheidsgevoelens, gevoelens van verwerping, aggressie, woede, angs, vrees en haat vir ander of vreemdelinge (xenofobie), gedurig op die verdediging wees, die beskerming van bendes soek, aan ekstreme gevoelens ly, oorgevoeligheid, en die neiging om affek en emosie te verberg.

Op die een of ander tydstip in hulle lewens moet persone wat sulke onreg gely het die oortredende party vergewe, anders ly hulle onder die gevolge van hulle eie onvergewensgesindheid. Die vrugte van onvergewensgesindheid is die volgende: teenoor die self - skuldgevoelens, selfveroordeling, skaamtegevoelens, onwaardigheidsgevoelens, selfhaat en selfmoordgedagtes; teenoor andere - haat, bitterheid, agterdog, wraak, jaloesie, moord; en teenoor God - twyfel, ongeloof, rebellie en die gevoel dat God ver weg is (Coetzer 2008:20).

Dieselfde geld vir gemeenskappe (Rodden 2004:333). Die geskiedenis wemel van voorbeelde waar een gemeenskap onreg teenoor 'n ander gepleeg het. ' $n$ Mens dink maar aan hoe die Judeërs diep veronreg gevoel het tydens die Babiloniese ballingskap. Meer onlangse voorbeelde is die verdrukking van die Jode deur Nazi-Duitsland voor en tydens die Tweede Wêreldoorlog (19321945), en die tydperk van die 'Troubles' in Noord-Ierland (Ulster) waartydens meer as 3000 mense aan die Lojalistiese sowel as die Republikeinse kant hulle lewens verloor het. Nog 'n voorbeeld is die onreg wat die mense in die Balkan- en die Baltiese state onder die kommunistiese regime van die destydse Unie van Sowjet-Sosialistiese Republieke gely het (1949-1989). Verder kan ook in 
hierdie verband genoem word dat groot getalle mense in die Verenigde State van Amerika tans veronreg voel deur die afkondiging van die presidensiële dekrete van president Donald Trump (vgl. diegene uit die sewe Moslemlande wat in Januarie 2017 verbied is om die VSA binne te kom ten spyte daarvan dat baie van hulle oor die vereiste 'groen kaarte' beskik het wat aan hulle verblyfreg gee). Die deurlopende spanning tussen ateïste en teïstiese gelowiges (Peck 2006:173), Moslems en die Westerse wêreld (Wright 2009:421), en tussen gematigdes en religieuse fanatici (ekstremiste, fundamentaliste) kan ook as voorbeeld gebruik word (Alford 2009:57).

Ook die Suid-Afrikaanse geskiedenis bevat voorbeelde van (gewaande en werklike) sosiale onreg. 'n Mens dink maar aan hoe die Afrikanergemeenskap die Britte verkwalik het oor laasgenoemde se behandeling van vroue en kinders tydens die Anglo-Boereoorlog (1899-1902). In die heel onlangse verlede vind ons dat die swart gemeenskap(pe) in Suid-Afrika 20 jaar na die beëindiging daarvan, steeds die apartheidsbedeling verkwalik vir die agterstande waaronder hulle vandag ly - soos aan die hand van die onderwys geillustreer kan word.

Die onderwyssituasie in Suid-Afrika lewer bewys van die gedagte dat apartheid tot vandag toe steeds vir die swak gehalte onderwys verkwalik word. Volgens Cele en Koen (2003) is Suid-Afrikaanse studente al sedert die sestigerjare van die vorige eeu besig met vraagstukke wat nasionale oplossings verg. Dit was egter vir swart studente moeilik om sulke oplossings te vind weens die apartheidsbedeling waarbinne hulle geleef het. Tot vandag toe word SuidAfrikaanse universiteite beskou as oorblyfsels uit die koloniale tydperk en as bastions van rassisme (Cloete 2016). Spaull (2013:6) kom tot die gevolgtrekking dat daar in werklikheid twee onderwysstelsels in Suid-Afrika bestaan: die kleiner en ryker stelsel ( $20 \%-25 \%$ van die bevolking) wat heelwat beter presteer as die ander stelsel vir die oorblywende, armer deel van die bevolking. Hierdie is ' $n$ nalatenskap van die apartheidsbedeling, aangesien leerders op grond van rykdom, sosio-ekonomiese status, geografiese woonplek en selfs taal verdeel word. Verskeie studies toon dat die leerders in die voorheen agtergeblewe gebiede tot soveel as ' $n$ twee tot twee-en-'n-half jaar agterstand het by diegene in dieselfde ouderdomsgroep in die meer bevoorregte gebiede. Van der Berg (2008:145) se siening klop hiermee as hy stel dat onderwysgehalte in die historiese agtergeblewe (swart) skole nie noemenswaardig verbeter het sedert die einde van apartheid in 1994 nie. Hy stem saam met Taylor (2007:537) dat die ingrepe wat in hierdie agtergeblewe skole gemaak is, nie juis enige verbetering in die skole se uitsette en prestasies meegebring het nie. Christie (2016:435) ondersteun ook hierdie siening. Daar is volgens haar nog steeds 'important lines of social fracture' in die Suid-Afrikaanse samelewing. Selfs twee dekades na die einde van apartheid bly die SuidAfrikaanse samelewing nog diep verdeeld en ongelyk: 'Despite some shifts in apartheid's race/class configuration, the burden of poverty and poor education are still shouldered disproportionately by black people.' Volgens Christie (2016:435) is hierdie 'n voorbeeld van sosiale onreg wat bly voortduur het na die beëindiging van apartheid.

Die doel van die voorafgaande bondige oorsig is om aan te toon dat daar baie gemeenskappe, en bes moontlik miljoene mense dwarsoor die wêreld is wat op hierdie tydstip die een of ander gevoel van onreg, argwaan, woede, onregverdigheid, ongeregtigheid, ontevredenheid, ontsteltenis, ongelukkigheid, haat, nyd, vyandskap en dies meer koester oor die een of ander sosiale onreg wat hulle persoonlik of hulle gemeenskap aangedoen is. Sodanige gevoelens het in die onlangse verlede aanleiding gegee tot ' $n$ hele aantal aanvalle en terreurdadewat op diegene gerig was wat as die oorsaak van die sosiale onreg beskou is. Daar is volop voorbeelde hiervan in die literatuur. Die VSA (2014:1-15) se Department of State's Bureau of Democracy, Human Rights and Labor se International Religious Freedom Report for 2014 doen verslag oor religieus onverdraagsame gedrag oor die ganse aardbol in reaksie op sosiale onreg wat deur aanhangers van die meeste van die groot godsdienste beleef is. Daar is verwysings na die optrede van die Islamitiese Staat in Irak, die Levant en Sirië. Die verslag noem ook anti-Semitiese, antichristelike, anti-Moslem en anti-Hindu optredes in verskeie dele van die wêreld. Ook die Mennoniete het in daardie jaar onder vervolging gely. Christene het hulle ook skuldig gemaak aan sulke sosiale onregverdigbare gedrag soos die aanvalle in die VSA op 'n Sikhtempel in Wisconsin in 2012, op 'n Unitariesuniversalistiese kerk in Tennesee Valley in 2008 en op die Centennial Olympic Park (Henderson 2013).

Die bekendste van hierdie dade is bes moontlik die aanval op die New Yorkse World Trade Centre op 11 September 2001. Die optrede van Boko Haram en van die Islamitiese Staat in Afrika en die Midde-Ooste is ook tipies van hierdie gesindheid van haat en vyandskap oor sosiale onreg wat gepleeg is (soos die VSA se invalle in Irak en Afghanistan) (Kagawa \& Selby 2014:26, 34-78). Dit is uit al hierdie voorbeelde duidelik dat daar onder baie individue en gemeenskappe 'n gesindheid van verharding, haat, nyd en vyandskap ingetree het, eerder as 'n gesindheid van vrede, versoening en vergifnis.

Die probleem is dat min mense intuitief weet wat vergifnis is, wat die elemente daarvan is, hoe kan of behoort vergewe te word, waarom daar moet of kan vergewe word, en wat die gevolge van onvergewensgesind teenoor ander mense of gemeenskappe is. Omdat geen mens van nature weet wat vergifnis is en wat die elemente en implikasies daarvan is nie moet hulle deur middel van opvoedende onderrig of onderwys daartoe gebring word om die dieptedimensies van vergifnis te verstaan en bemeester. Sonder sodanige opvoedende onderrig of onderwys bly vergifnis 'n abstrakte begrip. Dit moet konkrete betekenis met betrekking tot 'n bepaalde gemeenskap kry (Miedema \& Ter Avest 2011:411).

Die tweeledige navorsingsvraag van die ondersoek waarvan die uitkoms in hierdie artikel aangebied word, is reeds hierbo geïmpliseer: 
- Wat is vergifnis en waarom moet vergewe word? Wat is die elemente van vergifnis?; Wat is die implikasies van onvergewensgesindheid?; en Wat is die gevolge, resultate of uitkomste van opregte vergifnis oor onreg wat gepleeg is?

- Hoe kan 'n gesindheid van vergifnis teenoor andere wat die een of ander onreg teenoor'n persoon of 'n gemeenskap gepleeg het, by individue en/of gemeenskappe deur middel van opvoedende onderrig of onderwys (onder meer in die vorm van burgerskapsonderwys) tuisgebring word?

\section{Metode van ondersoek}

Die woordsamestelling vergifnisonderwys verwys na 'n teoretiese konstruk waarin vir teoretiese (wetenskaplike) doeleindes twee antropologiese ontisiteite ('dinge') saamgevoeg is, naamlik vergifnis en onderwys. Dit is die mens wat in staat is om te vergewe (maar dit nie altyd doen nie, of nie doeltreffend of tydig doen nie) en dit is ook die mens wat ander wat nog nie oor die nodige volwassenheid beskik nie kan onderrig, toerus, lei en begelei om te verstaan wat dit beteken om te vergewe (maar dit ook nie altyd wil of kan doen, of behoorlik wil of kan doen nie). Ten einde 'n nog dieper insig te verkry in dít wat as die inhoud van die konstruk vergifnisonderwys beskou kan word, moet die konstruk ook opvoedkundig-teoreties bewerk word. Sodanige teoretiese bewerking het vier kernoogmerke: Eerstens, dit stel die wetenskaplike (opvoedkundige) in staat om die situasie wat die konstruk voor die gees roep, te verbeeld en te beskryf; tweedens, dit stel hom of haar in staat om diskoers te voer oor die konstruk en die inhoud daarvan; derdens, dit stel hulle in staat om bepaalde afleidings vir teorie (wetenskap, die opvoedkunde) sowel as praktyk (onderwys en opvoeding) aangaande die inhoud van die konstruk te maak; en vierdens, dit stel hulle in staat om bepaalde praktiese toepassings van bevindings aangaande die konstruk te maak (Halverson 2002:245)

Vir doeleindes van hierdie ondersoek ten einde hierdie vier teoretiese bewerkingsoogmerke te bereik, word die konstruk hieronder bekyk en ontleed deur die lens van die sosiale ruimte en etiese funksieteorie (Van der Walt 2017:1-8). Deur middel van hierdie waarneming en ontleding kan die volgende bereik word: die aantoning van sosiale ruimtes waarin vergifnis nodig is, en waar en hoe vergifnisonderwys nodig is en aangebied moet word (die belangstelling sal in hierdie geval uiteraard in die pedagogiese ruimte wees). Voorts sal die moreel-etiese kant van vergifnis en van vergifnisonderwys na vore gebring word. Laasgenoemde is noodsaaklik omdat vergifnis 'n etiese figuur is (dit funksioneer in die etiese aspek van die werklikheid). Omdat uitsprake oor wat as moreel-eties beskou moet of kan word leeg en sinloos is indien hulle nie op 'n religiouslewensbeskoulik-etiese normatiewe onderbou berus nie, is sodanige onderbou (vir doeleindes van hierdie ondersoek) op skriftuurlike (bybelse) gronde ontwikkel (kyk bespreking hieronder). Met hierdie onderbou word verdiepte normatiewe rigting aan vergifnis en vergifnisonderwys gegee. Hoewel hierdie onderbou uiteraard religieus-partikularisties is, kan dit stof tot nadenke bied ook aan persone wat vergifnis en vergifnisonderwys as belangrik en noodsaaklik ag hoewel hulle self nie die bybelse perspektiewe en riglyne as normatief in en vir hulle eie lewens en onderwys beskou nie (De Botton 2012:160).

Om redes wat hieronder in meer besonderhede bespreek word, word burgerskapsonderwys as die mees gepaste skoolvak beskou om vergifnisonderwys te akkommodeer. Dit gaan in hierdie artikel egter nie oor burgerskapsonderwys as sodanig nie. ${ }^{1}$

\section{Vergifnis en vergifnisonderwys deur die lens van die sosiale ruimte en etiese funksieteorie}

Die sosiale ruimte en etiese funksie- of handelingsteorie omvat, soos deur Van der Walt (2017, voetnota 5) uiteengesit, twee hoofmomente, te wete die gedagte van 'n sosiale ruimte waarin gebeure of handelinge geskied asook die gedagte dat hierdie gebeure, handelinge of funksies aan eties-morele norms moet voldoen. Hierdie twee gedagtes word hierna agtereenvolgens uiteengesit en elkeen word daarna as ' $n$ lens gebruik waardeur burgerskapsonderwys (as die voertuig of die raamwerk waarbinne vergifnisonderwys aangebied kan of behoort te word) sowel as vergifnis en vergifnisonderwys van nader bekyk en beskryf word.

\section{Die sosiale ruimte-moment}

Die sosiale ruimte en etiese funksieteorie stel ten eerste dat individue, groepe en samelewingsverbande soos gesinne, families, skole, besighede, universiteite en sportklubs asook handelings en gebeure elkeen 'n eie besondere sosiale ruimte in die menslike leefwêreld beslaan. Ruimte kan omskryf word as die plek waar mense en hulle verbande hulleself fisies en/of liggaamlik oriënteer in die werklikheid (Verburg 2015:420). Hierdie handelings en gebeure vind binne die kosmiese wetsraamwerk van sosiale interaksie plaas (Verburg 2015:203). Die nadruk word in hierdie bespreking op die sosiale funksie van menslike bestaan gelê sonder om daarmee te kenne te gee dat die sosiale die enigste of die belangrikste funksie van die werklikheid is. Soos Mahlomaholo (2014:172-173) tereg aandui, is die sosiale maar een van die funksies van die werklikheid en is dit met al die ander verweef.

Die teorie stel voorts dat, anders as in 'n ongedifferensieerde of 'natuurlike' samelewing (Verburg 2015:355), elke individu, groep of samelewingsverband met eie 'n skeppingsmandaat, funksie, doel of roeping toevertrou is. Elkeen moet sy funksie en doel met toewyding, verantwoordelikheid en toerekenbaarheid nastreef asook met die verskuldigde eerbied vir die sosiale ruimtes, selfbepaling en funksies van alle ander individue, groepe en samelewingsverbande.

1.Goeie argumente sou ook kon wees dat dit in studiegebiede soos geskiedenis, sosiale studies, menseregte-onderwys (Roux 2012:2), onderwys vir volhoubaarheid sosiale studies, menseregte-onderwys (Roux 2012:2), onderwys vir volhoubaarheid
of onderwys vir internasionale begrip aangebied behoort te word (UNESCO of onderwy. 
Kagawa en Selby (2014:11) stel dit dat sosiale ruimtes waarin elkeen homself kan uitleef - selfs diegene wat hulleself 'anders' as die res beskou - behoort te bestaan. Daar moet dus ook sosiale ruimte vir diversiteit geskep word. Van Goor, Heyting en Freeke (2004:187) stem saam dat kennis geneem behoort te word van dít waaraan 'n ander sin heg om daarmee ruimte vir andere te skep. Hierdie gedagte word soms verwoord as 'being socially connected' (UNESCO 2015:23).

Die probleem hier, soos Tripp (2010:105) aantoon, is dat die natuurlike selfsugtigheid van die mens hom of haar daartoe noop om 'n ander persoon nie die nodige ruimte te gun nie, en om sodoende soewereiniteit (heerskappy) te wil voer oor 'n self-omskrewe eie klein wêreld waarin jy alles kry waarna jy verlang (vgl. Gen 3). So 'n eie klein sosiale ruimte kan dan onder bepaalde omstandighede ook die diepste grond of regverdiging wees vir 'n bepaalde siening of standpunt (Van Goor et al. 2004:38).

Die eerbied of respek waarvan hierbo sprake is, vind uitdrukking in die toepassing van die beginsel van soewereiniteit in eie kring sowel as in die teenhanger daarvan die beginsel van universaliteit in eie kring (Verburg 2015:64, $100,107)$. Hierdie twee beginsels verwys onderskeidelik na die relatiewe outonomie wat elke individu, groep of samelewingsverband in die betrokke sosiale ruimte besit. Daarteenoor verwys dit na die verweefdheid van saamlewe: een mens leef saam met ' $n$ ander, een groep leef saam met ' $n$ ander en een samelewingsverband is met ' $n$ ander verweef omdat hulle dieselfde mense as lede het (dieselfde persoon kan 'n ouer in die gesin, 'n eggenote in 'n huwelik, 'n lidmaat van die kerk en 'n burger van die staat wees).

Volgens die literatuur vind burgerskapsonderwys 'n sosiale ruimte in die pedagogiese werklikheid (vgl. Miedema \& Ter Avest 2011:421; UNESCO 2015:19). In sommige lande soos Australië, Colombië, Indonesië, Tunisië, Engeland vind die aanbieding van burgerskapsonderwys dwarsoor die skoolkurrikulum plaas; dit wil sê, daar word in verskeie skoolvakke (interdissiplinêr) daaraan aandag geskenk (De Cicco 2016:6). In ander lande soos die Republiek van Korea maak die kurrikulum voorsiening vir 'n spesiale skoolvak, naamlik 'Kreatiewe ervaringsaktiwiteite', en in Sri Lanka vir 'n spesiale skoolvak genaamd 'Onderwys vir sosiale kohesie'. In Suid-Afrika, byvoorbeeld, is dit met vakke soos Lewensvaardighede en Lewensoriëntering geïntegreer (vgl. DBO 2011 - Grade R-3, afdelings 4; 8; Grade 7-9, afdeling 8; Grade 10-12, afdeling 7). Daar bestaan ook heelwat voorbeelde van die informele of nie-formele aanbieding daarvan deur nie-regeringsorganisasies soos die ACTIVATEprogram in Suid-Afrika, die HIGH RESOLVES-program in Australië en die PEACE FIRST-program in die Verenigde State van Amerika (UNESCO 2015:47-49).

Welke model ook al verkies word vir die aanbieding van burgerskapsonderwys, dit behoort 'n konkrete verbesondering vir die betrokke samelewing te wees (Miedema \& Ter Avest 2011:411). As pedagogiese (Bildungs-) handeling, dit wil sê vormende handeling of proses, moet dit die leerlinge help om eie sienings te ontwikkel aangaande die plurale en diverse lewe in hulle lande, en om hulle eie identiteit te ontwikkel in die prosesse van selfverantwoordelike selfbepaling. Met hierdie standpunt ondersteun hulle die siening van Banks (2008:129) dat burgerskapsonderwys die leerlinge moet help om die kennis, vaardighede en waardes te verwerf wat hulle benodig ten einde doeltreffend te kan funksioneer in hulle eie onmiddellike kulturele omgewing, streek, nasiestaat en ook in die globale gemeenskap. Die kuns hierby, so meen hy (Banks 2008:130), is om die leerlinge so te begelei dat hulle burgerlike gemeenskappe kan opbou wat die diversiteit onder die burgers van die land kan reflekteer en inkorporeer, en tegelyk ook 'n oorkoepelende nasionale en internasionale stel gedeelde waardes, ideale en doelstellings kan opbou. Burgerskapsonderwys behoort van sodanige aard te wees dat elke leerling 'n menslike verbinding vorm met mense regoor die hele wêreld en tog ook'n multikulturele siening opbou, naamlik een wat die reg en behoefte van elke leerling erken om tot die waardes van sy of haar eie kulturele gemeenskap verbind te wees tot dié van 'n transnasionale gemeenskap en van die nasiestaat waartoe hulle behoort (Banks 2008:134).

Dit is nou binne hierdie sosiale (pedagogiese of burgerskapsonderwys-) ruimte dat ook vergifnisonderwys 'n plek kan of behoort te kry. Sover vasgestel kon word, word vergifnisonderwys nêrens as 'n spesifieke of standaard skoolvak in skole aangebied nie. Daar is, wat hierdie kennisgebied in skole betref, twee hoofbenaderings. Die eerste is om, soos die Suid-Afrikaanse kurrikulum doen, ruimte daarvoor te skep sonder om dit by die naam te noem. Die tweede is om, wanneer nodig, dit as 'n spesiale ingryping (intervensie) in skole aan te bied. In die meeste gevalle, soos hieronder aangedui, vind hierdie intervensies egter plaas as deel van navorsing oor die vraag of vergifnisonderwys geslaagd en doeltreffend was.

Wat eersgenoemde benadering betref, kan na die SuidAfrikaanse kurrikulum (DBO 2011) verwys word. In afdeling 4(c) van die Grondslagfase word gestel dat sosiale transformasie nodig is ter wille van die regstelling van onderwysongeregtighede van die verlede en dat sosiale geregtigheid moet geskied. Afdeling 8 stel dat leerlinge begrip moet kry vir die verhoudings tussen mense, vir oorsaak en gevolg, verhoudings, interafhanklikheid en persoonlike welsyn. Afdeling 9 verwys na sosiale gesondheid, verhoudings met ander mense, waardes en gesindhede, ingeligte en moreel verantwoordelike en verantwoordbare besluitneming, positiewe verhoudinge met die eie gesin, familie en gemeenskap, en die noodsaaklikheid van verdraagsaamheid. In afdeling 9 van die Intermediêre Fase word verwys na positiewe verhoudings met die self, die gesin, die familie en die gemeenskap, die omgewing en die gemeenskap, ingeligte keuses met betrekking tot leefstyl, en sosiale welsyn. Afdeling 8 van die Senior Fase wys op die belangrikheid van die holistiese ontwikkeling van leerders deur hulle onder meer vir 'n sinvolle en suksesvolle lewe in 'n vinnig veranderende en transformerende samelewing toe te rus. Die fokus van die vakgebied Lewensoriëntering is die 
ontwikkeling van die self-in-gemeenskap, individuele groei, verbeterde gehalte van lewe en ingeligte keuses met betrekking tot persoonlike en omgewingsgesondheid. Afdeling 9 van die Verdere Onderwys- en Opleidingsfase meld die volgende sake wat regstreeks met vergifnisonderwys verband kan hou: verhoudings en hulle betekenis vir welsyn, gesonde leefstylkeuses en besluitneming, streshantering, konflikoplossing, hedendaagse samelewingsvraagstukke, sosiale vaardighede en verantwoordelikhede, diversiteit, diskriminasie, menseregte en die oortreding daarvan, die noodsaaklikheid van ' $n$ harmonieuse samelewing, verantwoordelike burgerskap, en die impak van sosioekonomiese faktore.

Dit is uit die voorgaande bondige oorsig van die SuidAfrikaanse skoolkurrikulum duidelik dat daar baie ruimte vir vergifnisonderwys geskep is. Daar is baie geleenthede in die kurrikulum waar die leerlinge kan leer wat sosiale onreg is, hoe 'n mens jou daarteenoor behoort in te stel, wat vergifnis is, en wat die stappe is wat geneem kan word om iemand te vergeef wat teen jou oortree het, en wat met jou gebeur indien jy 'n onvergewensgesinde houding inneem.

\section{Die eties-morele moment}

Die tweede moment wat deur die sosiale ruimte en etiese handelings- of funksieteorie omvat word, is dié van eties-morele gedrag wat van elke deelnemer in die betrokke sosiale ruimte verwag word. Elke individu, groep en samelewingsverband is verplig om toegewyd sorg te dra vir die belange van alle ander mense en groepe. Hierdie beginsel is in die verlede op verskeie maniere verwoord, onder meer om jou naaste so lief te hê as jouself (Matt 5:43), om om te gee vir die persoon en die belange van andere (Stoker 1967:231), Kant se kategoriese imperatief (Kenny 2012:699) of Rousseau se stelreël om aan andere te doen soos jy graag aan jouself gedoen wil hê (Comte-Sponville 2005:9).

Deur eties-moreel op te tree, word daar aan alle individue, groepe en samelewingsverbande die ruimte verskaf om hulle eie betekenisvolheid in die lewe uit te leef en tot uitdrukking te bring, om begrip en eerbied vir die diversiteit in die samelewing te toon (UNESCO 2015:23), en om daardeur waarde aan die hele mensdom toe te voeg. UNESCO (2015) het hierdie gedagtes onlangs in ' $n$ publikasie vasgevang met die woorde:

to be ethically responsible and engaged; (to respect) the values of caring for others, for personal and social responsibility and transformation, participating in the community and contributing to a better world through informed ethical, and peaceful action. (p. 24)

Met bogenoemde stelling eggo hierdie internasionale liggaam verskillende gedagtes, uitgespreek deur Nussbaum (2012:21, 25, 28, 57, 91), naamlik dat daar eerbied vir mense, hulle waardigheid en gelykheid met andere behoort te wees, dat 'sympathetic imagination' met andere en hulle omstandighede betoon moet word en dat barmhartigheid ('compassion') teenoor hulle behoort te blyk. Selfs wanneer 'n mens bang is vir ander mense of groepe '(such) fear should be moralised by sympathy' - selfs tot by ' $\mathrm{n}$ situasie van 'unselfing' waarmee selfsugtige gedrag teëgewerk word (vgl. Tripp 2010:105 - kyk hierbo). Die eerbied wat hier ter sprake is, meen Nussbaum (2012:119), behoort nie alle kritiese gesprek te smoor nie, maar moet juis sosiale ruimte skep, dit wil sê die ruimte wat mense benodig om hulle gewetens uit te leef - of ander saamstem met wat hulle in hulle sosiale ruimte doen of nie. Roux $(2012: 29,47)$ stel verder dat sulke ruimtes nie permanent van aard is nie; dit verander na gelang van die betrokkenes se omstandighede en moet dan geherdefinieer word.

Vanuit die sosiale ruimte waarin 'n mens jouself bevind, behoort daar ook morele verbeelding ('moral imagination') ten opsigte van ander en hulle sosiale ruimtes aan die dag gelê te word. Dit is enersyds moontlik, meen Bower (2005:231), omdat alle mense ten diepste etiese of morele wesens is, en andersyds is dit noodsaaklik ter wille van vreedsame naasbestaan (modus vivendi: erkenning van die feit dat die mens en die menslike samelewing voordeel kan trek indien aanvaar word dat 'n verskeidenheid van leefstyle en menings naasmekaar kan bestaan, en dat daar by ander geleer kan word hoe om met menswees om te gaan) (Grayling 2002: 7-8). Morele verbeelding, aldus Wright (2009:419), is die vermoë om op 'n intieme vlak te verstaan wat iemand anders se dade (in sy of haar sosiale ruimte) motiveer, en om in staat te wees om daardie persoon se ervaring as 't ware virtueel met hom of haar te deel en dit sodoende waarlik te ken.

Hierdie soort morele verbeelding, stel Wright (2009:419), is relatief maklik om toe te pas met familie en vriende, maar is baie moeiliker in die geval van mense wat as teenstanders of as vyande beskou word. Hy skryf onder meer: 'the bulk of Westerners and the bulk of Muslims are in a deeply non-zero-sum relationship, [and] by and large aren't very good at extending moral imagination to one another' (Wright 2009:421). Hierteenoor, stel Nussbaum (2012:97), behoort daar eerder die gesindheid van die stylvolle gasvrou aangeneem te word deur vir die ander te sê dat 'n mens hulle en hulle omstandighede graag beter wil leer ken en verstaan, en graag die wêreld vir hulle beter en geriefliker wil maak. Cockerill (2014:14) meen dat sulke morele verbeelding deur middel van etiese navraag, reflektiewe praktyk en sosiale handeling toegepas kan word. Deur dit te doen, voeg Needleman (2008:78-105) by, kan'n positiewe gesindheid en reaksie by die ander uitgelok word. Op hierdie manier kan daar geleer word om na 'n ander persoon te luister en nie net na sy of haar redenasie nie, en daar kan tot die besef gekom word dat alle handelinge van hierdie aard van 'n diepe morele aard is. Daar vloei volgens Needleman 'n sekere energie wanneer een persoon intensief na 'n ander luister. Hy (Needleman 2008:105) kom tot die gevolgtrekking dat daar op hoër vlakke na hierdie energie as liefde verwys kan word.

Dit is uit die literatuur duidelik dat skrywers die mening huldig dat burgerskapsonderwys al die voorgaande sentimente oor die eties-morele behoort te weerspieël. UNESCO (2015:15-24) stel dat hierdie vak die kennis, waardes, 
vaardighede en gesindhede moet kweek wat mense nodig het om tot 'n meer inklusiewe, regverdige en vreedsame wêreld te kan bydra. Hulle moet daarby gesindhede van sorg, empatie en eerbied vir andere kweek, hulle moet leer om eties verantwoordelik en betrokke te wees, hulle moet kan nadink oor etiese konflik wat uit sosiale en politieke verantwoordelikhedespruit, en hullemoet ook barmhartigheid aanleer vir andere. Die burgerskapsonderwysklaskamer moet deur 'n eerbiedvolle en inklusiewe skool-etos gekenmerk word (UNESCO 2015:53). De Cicco (2016:3-6) brei hierdie lys van gesindhede, waardes en vaardighede soos volg uit: Leerlinge moet leer om medelye met hulle medemens te hê, hulle moet 'n morele verantwoordelikheid ontwikkel ten einde tot 'n beter wêreld vir almal te kan bydra, hulle moet leer om sosiale geregtigheid toe te pas deur krities oor bestaande ongelykhede in hulle gemeenskappe na te dink, en hulle moet die regte van alle mense eerbiedig en verantwoordelik teenoor andere voel en optree. Kortom, hulle moet ' $n$ dringendheid en ' $n$ morele verantwoordelikheid aan die dag te lê om iets aan onregverdige situasies te doen. Hulle behoort, soos Banks (2008:135) dit stel, te leer om aan die lewe deel te neem op maniere wat die demokrasie, gelyke behandeling en sosiale geregtigheid in hulle eie en in ander gemeenskappe bevorder, en hulle moet diversiteit erken en reg benader deur onder meer inklusiwiteit te bevorder.

Dit is binne hierdie raamwerk van verwagte eties-morele gedrag wat leerlinge behoort te ontwikkel deur blootstelling aan burgerskapsonderwys dat vergifnisonderwys aangebied behoort te word.

Soos hierbo vermeld, was daar oor die afgelope ongeveer vier dekades heelwat vergifnisonderwysingrypings (-intervensies) wat eerder met navorsing verband hou as wat hulle organies en integraal deel van die betrokke land of streek se kurrikulum vorm. Die volgende kan as voorbeelde hiervan genoem word: 'n Vergifnisonderwysingryping is gedoen met kinders wat die liefde van hulle ouers ontbeer het en as gevolg daarvan verwaarloos en woedend gevoel het (Al-Mabuk, Enright \& Cardis 1995). 'n Ingryping is ook gedoen onder wanaangepaste adolessente wat ongesonde vlakke van aggressie getoon het (Schechtman \& Nachshol 1996) en ook een onder adolessente wat emosionele probleme ondervind het weens hulle ouers se egskeidings (Freedman \& Knupp 2003). Enright, Gassin en Knutson (2003) het 'n ingryping gedoen onder kinders wat weens die geweld in Noord-Ierland getraumatiseerd geraak het. CastillejoCuéllar (2007) bespreek die werk van die Waarheids- en Versoeningskommissie in Suid-Afrika as 'n soortgelyke eenmalige en kortstondige ingryping. Park et al. (2013) het 'n proefondervindelike ingryping geloods onder SuidKoreaanse dogters wat uitermate hoë vlakke van aggressie getoon het. ' $n$ Ingryping van vergelykende navorsingsaard is deur Enright et al. (2014) gedoen onder twee groepe Amerikaanse jeugdiges wat min begrip vir mekaar getoon het. Taysi en Demet (2015) het 'n soortgelyke ingryping onder armoedige en verwaarlooste Turkse kinders gedoen.
Al hierdie ingrypings soos deur die verskillende navorsers gemeet, was geslaagd. Soos een van die navorsers, Enright (2003:26), in sy boek oor vergifnis en vergifnisonderwys stel: Vergifnis en vergifnisonderwys werk! Wat verder opvallend is van al die vermelde ingrypings en geskrifte oor vergifnis en vergifnisonderwys is dat, hoewel hulle uit 'n sekulêre oogpunt gedoen en geskryf is (d.w.s. sonder dat die navorsers of skrywers hulleself pertinent aan enige godsdienstige oortuigingsraamwerk verbind), hulle deurentyd die nadruk op die moreel-etiese belangrikheid en noodsaaklikheid van vergifnis en die aanbied van vergifnisonderwys lê. Die volgende is maar net enkele sprekende voorbeelde hiervan:

Al-Mabuk et. al. (1995) stel dat'n persoon teenoor wie oortree is, moet leer om die ander se menslikheid te ken en respekteer. Dit is die voorloper van empatie en barmhartigheid wat tot heling kan lei. Na hulle oordeel behoort morele onderwys ook vergifnisonderwys in te sluit, aangesien mense dikwels voor morele dilemmas te staan kom soos byvoorbeeld die vraagstuk van sosiale ongeregtigheid. Hulle beklemtoon ook die waarde van genadebetoning aan die oortreder. Schechtman en Nachshol (1996:537) beklemtoon op hulle beurt die belangrikheid dat die persoon teenoor wie die onreg gepleeg is, empatiese emosies teenoor die oortreder moet betoon. Freedman en Knupp (2003:141) lê die nadruk daarop dat vergifnis 'n alternatief vir woede oor onreg is. Enright (2003:7, 13, 18, 25-26, 37-38) noem oortredings teen 'n mens en vergifnis 'morele vraagstukke' en dat heling en vrymaking deur vergifnis verkry kan word, dat die regte van ander eerbiedig behoort te word en dat vergifnis ' $n$ genadedaad teenoor die oortreder is, dat vergifnis 'n voorbeeld is van hoe die goeie oor die bose kan seëvier, hoedat vergifnis nie slegs 'n 'grim obligation' behoort te wees nie, maar 'n voorreg, hoedat die oortreder se menslikheid eerbiedig moet word, en hoedat 'n mens jouself sodoende respekteer. Enright et al (2003:4) sluit hierby aan en stel dat om te vergewe nie uit swakheid gedoen word nie, maar uit 'n posisie van mag en dat dit 'n persoonlike handeling teenoor die oortreder is. Rodden (2004:334) bespreek ' $n$ hele aantal fasette van vergifnis en vergifnisonderwys waarvan die belangrikste moontlik die volgende stelling is: om in staat te wees om te vergewe, is ' $n$ teken van 'n gevorderde stadium van morele ontwikkeling. Castillejo-Cuéllar (2007) toon op sy beurt aan dat om te vergewe aan 'n mens ' $n$ 'moment van hernuwing' skenk. Taysi en Demet (2015) wys verder daarop dat vergifnis woede kan laat afneem en die skadelike uitwerking van die onreg of oortreding op die persoon wat daar onder gely het, verlig. Gregory (2016:16) kom na oorweging van vorige navorsing oor vergifnis en vergifnisonderwys, tot die gevolgtrekking dat om te vergewe voordelig is vir die slagoffer van 'n oortreding.

\section{Vergifnis en vergifnisonderwys vanuit Skriftuurlike perspektief}

Dit is uit die voorafgaande oorsig van burgerskapsonderwys, vergifnis en vergifnisonderwys duidelik dat skrywers en navorsers op hierdie terrein volle erkenning aan die etiesmorele kant van vergifnis en van vergifnisonderwys gee. Die 
probleem is egter dat die konsep eties-moreel eintlik 'leeg' bly indien dit nie met religieuse betekenis gevul word nie en indien daar nie geloofs- of pistiese rigting aan verleen word nie. Parekh (2000:130,150,158) verwys na so'n etiese standpunt as 'n vorm van 'dun', dit wil sê minimalistiese universalisme. Strauss (2009:102) se stelling dat '... terms like certainty, trust, confidence and reliability are (synonymous) designations of the core meaning of the faith aspect' impliseer dat die sekerheid, vertroue en betroubaarheid wat 'n mens in jou geloof in God (of in die een of ander plaasvervanger-god) het, rigting en leiding aan al die ander funksies van menswees gee; dus ook aan die sosiale en die etiese wat met die liefde vir die naaste en die behartiging van sy of haar persoon en sy of haar belange te make het. Op die heel diepste vlak van menslike bestaan verenig ('unifies') 'n mens se geloof dit en gee rigting daaraan, hetsy in diens van iets in die skepping of as heelhartige liefdevolle diens aan God en die naaste (Strauss 2009:314).

In die lig hiervan is dit nou nodig om kortliks (noodgedwonge, weens die beperkte lengte van 'n tydskrifartikel) in te gaan op wat vergifnis en vergifnisonderwys vanuit 'n pertinent skriftuurlike oogpunt beteken. Deur dit te doen, word geloofsdiepte en -inhoud aan die konsep vergifnis verleen en daardeur word ryker insig in vergifnis en vergifnisonderwys verkry. $^{2}$

Volgens die Skrif is die volgende sommige van die hoofredes waarom skrifgelowige mense verplig is om te vergeef in gevalle waar daar teenoor hulle oortree is of 'n sosiale onreg teenoor hulle gepleeg is:

Om te vergeef is 'n regstreekse opdrag van God in die Skrif (Matt 5:43-44; 6:12; 6:14-15; 18:21-22; Mark 11:25; Luk 17:3-4; Kol 3:12-13; Gal 5:14).

'n Mens behoort te vergeef omdat en soos God jou vergeef het (in Christus) (Luk 15:20-24; Ef 4:31-32; 5:1-2) .

Vergifnis moet gegee word omdat 'n mens jou medemens so lief soos jouself het of behoort te hê (2 Kor 2:7-8); vergelyk die genesing van die verlamde man (Mat 9:1-8), Jesus se tuisgaan by Saggeus ten spyte van sy vervreemding van sy volk (Luk 19:1-10), en die vergifnis aan die owerspelige vrou (Joh 8:1-11).

Vergifnis moet geskenk word uit dankbaarheid vir die vergifnis wat die Christengelowige in en deur Jesus Christus ontvang het (Mat 18:35; Hand 2:38; 13:38-39; 2 Kor 2:10; Ef $1: 7 ; 4: 31-32 ; 5: 1-2)$.

Vergifnis is 'n genadedaad aan 'n oortreder (Jak 2:13; 2 Kor 2:10), 'n betoning van liefde (Mat 5:39; 5:43-44;

2. Hierby moet daar egter in gedagte hou dat met hierdie stap 'n religieuspartikularistiese siening van vergifnis en vergifnisonderwys ontwikkel word - een partikularistiese siening van vergifnis en vergifnisonderwys ontwikkel word - een wat slegs vir Christene aanvaarbaar en sinvol sal wees en in Christelike verbondshuisgesinne, kerke en Christelike privaatskole toepaslik sal wees. In sekulêre onderwyskringe sal die siening wat hierna uiteengesit word, te eksklusief wees - dit sal nie van toepassing wees op diegene wat nie die Christelike geloo aanhang nie. Dit staan enige persoon of groep natuurlik vry om sodanige partikularistiese siening vir hulle en vir hulle besondere godsdienstige of geloofsgroep uit te werk.
Rom 12:17; 12:19; 2 Kor 14-15; 1 Pet 3:9) en 'n seën aan die oortreder (Spr 25:21-22; Mat 5:44; Luk 6:27-28; Rom 12:20).

Vergifnis behoort gegee te word ter wille van vredevolle naasbestaan tot eer en in diens van God (Rom 12:19). Vergifnis oorkom die kwade met die goeie (Rom 12:9-21).

'n Mens behoort te vergewe omdat andere jou vergeef (Mat 6:14-15; Luk 11:4).

'n Mens behoort te vergeef, want daardeur word die kwaad oorkom en die werk van die Satan teengewerk (2 Kor 1-11).

Vergifnisonderwys, hetsy in Suid-Afrikaanse skole in die konteks van Lewensoriëntering (laer grade) of van Lewensvaardighede (die hoogste drie grade), of elders soos byvoorbeeld in die kerk (vgl. Magnuson \& Enright 2008), die verbondsouerhuis, die Christelike privaatskool, ensovoorts. Vergifnisonderwys moet verder of as ' $n$ ingryping (soos hierbo beskryf) moet aan jongmense gebied word om hulle te lei, te ontvou en toe te rus om die bovermelde beginsels van vergifnis (Deut 4:9; 11:19; Jes 38:19; Joel 1:3; Ef 6:4), en die daarby behorende vaardighede van vergifnis doeltreffend in die praktyk van hulle latere lewens te kan toepas (vgl. Fowler, Van Brummelen \& Van Dyk, 1993: 155-168; Nussbaum, 2011: 23-25). Volgens Coetzer (2008:21) is dit noodsaaklik dat daar vanaf die vroegste stadium leiding aan kinders gegee word oor waarom en hoe om te vergeef. Hoe vroeër dit aangeleer word, hoe beter, aangesien dit later groot pyn in hulle lewens kan voorkom.

\section{Slot}

Om te kan vergeef wanneer 'n oortreding teenoor jou begaan is of 'n sosiale of ander onreg teenoor jou gepleeg is, is geen eenvoudige saak nie. Die Skrifgelowige kan die plig om te vergeef desondanks nie ontduik nie. Daaroor is die Bybel duidelik. Die sosiale ruimte en etiese funksie - of handelingsteorie wat hierbo gebruik is as lens om die vraagstuk van vergifnis en van vergifnisonderwys van nader te bekyk, het aan die lig gebring dat daar wel op verskeie plekke in die huidige onderwysbedeling van verskillende lande en ook van SuidAfrika die nodige pedagogiese ruimte bestaan om die vaardighedevanvergifnis deurmiddelvanvergifnisonderwys aan die opkomende geslagte te onderrig. Dit het daarby ook geblyk dat vergifnis 'n diep etiese en geloofsdimensie het wat deur verskillende geloofsgemeenskappe in die konteks van hulle eie onderskeie geloofsraamwerke tot uitdrukking gebring en tot praktyk gemaak kan en behoort te word. Dit het veral ook geblyk dat vergifnisonderwys, binne die raamwerk van burgerskapsonderwys, die sleutel kan wees tot die ontlonting van ongelukkigheid oor allerlei vorms van sosiale onreg wat in en tussen individue, en in en tussen gemeenskappe gepleeg word.

\section{Erkenning}

Die ondersteuning van die PUK-Kanselierstrust wat hierdie publikasie moontlik gemaak het, word hiermee met dank erken. 


\section{Mededingende belange}

Die outeur verklaar dat hy geen finansiële of persoonlike verbintenis het met enige party wat hom nadelig of voordelig kon beïnvloed het in die skryf van hierdie artikel nie.

\section{Literatuurverwysings}

Alford, H., 2009, How to live: A search for wisdom from old people, Twelve Books, New York.

Al-Mabuk, R., Enright, R.D. \& Cardis, P., 1995, 'Forgiveness education with parentally love-deprived late adolescents', Journal of Moral Education 24(4), 427-444, viewed 15 March 2017, from www.tandfonline.com/doi/abs/10.1080/03057249 viewed 15
50340405

Banks, J.A., 2008, 'Diversity, group identity, and citizenship education in a global age', Educational Researcher 37(3), 129-139. https://doi.org/10.3102/0013189X0 8317501

Bower, C., 2005, Open minds, closed minds and Christianity, Aardvark Press, Valyland.

Castillejo-Cuéllar, A., 2007, 'Knowledge, experience, and South Africa's scenarios of forgiveness', Radical History Review97, 11-42. https://doi.org/10.1215/016365452006-011

Cele, G. \& Koen, G., 2003, 'Student politics in South Africa - An overview of key developments', Cahiers de la Recherche sur l'education et les savoirs 2, 201-223, viewed 03 May 2016, from https://cres.revues.org/1517

Christie, P., 2016, 'Educational change in post-conflict contexts: Reflections on the South African experience 20 years later', Globalisation, Societies and Education 14(3), 434-446. https://doi.org/10.1080/14767724.2015.1121379

Cloete, N., 2016, 'A "third force" in higher education student activism', University World News, 403, 04 March, viewed 3 May 2016, from www.universityworldnews. World News, 403, 04 March, viewed 3 May 2016
com/article.php?story=2016030410040021

Cockerill, M., 2014, 'Beyond education for economic productivity alone: The capabilities approach', International Journal of Educational Research 66, 13-21. https://doi.org/10.1016/j.ijer.2014.01.003

Coetzer, W., 2008, Vergifnis, ongepubliseerde kursusbundel (SE Coetzer), Potchefstroom.

Comte-Sponville, A., 2005, The little book of philosophy, Vintage/Random House, London.

DBO sien Departement van Basiese Onderwys.

De Botton, A., 2012, Religion for atheists, Hamish Hamilton, London.

De Cicco, M.C., 2016, 'Global citizenship education within a context of accountability and 21st century skills: The case of Olympus High School', Education Policy Analysis Archives suppl. ser. 24, 1-21.

Departement van Basiese Onderwys, 2011, Curriculum and Assessment Policy Statement. National Curriculum Statement, Foundation Phase Life Skills/ Intermediate Phase Life Skills/Senior Phase Life Orientation/Further Education and Training Phase, Departement van Basiese Onderwys, Pretoria.

Enright, R.D., 2003, Forgiveness is a choice, American Psychological Association, Washington, DC.

Enright, R.D., Gassin, E.A. \& Knutson, J.A., 2003, Waging peace through forgiveness education in Belfast, Northern Ireland: A review and proposal for mental health improvement, viewed 04 April 2017, from global.wisc.edu/peace/readings/irwinwaging-peace-i.pdf

Enright, R.D., Rhody, M., Litts, B. \& Klatt, J.A., 2014, 'Piloting forgiveness education in a divided community: Comparing electronic pen-pal and journaling activities across to groups of youth', Journal of Moral Education 43(1), 1-17. https://doi. org/10.1080/03057240.2014.888516

Fowler, S, Van Brummelen, H.W. \& Van Dyk, J., 1993, Christian Schooling: Education for freedom, Institute for Reformational Studies, Potchefstroom. (Series F3,39).

Freedman, S. \& Knupp, A., 2003, 'The impact of forgiveness on adolescent adjustment to parental divorce', Journal of Divorce and Remarriage 39(1/2), 135-165. https:// doi.org/10.1300/J087v39n01_08

Grayling, A.C., 2002, The meaning of things, Phoenix, London.

Gregory, A., 2016, 'Promoting bullying prevention and intervention through forgiveness education', viewed 10 March 2016, from http://scholarworks.uni.ed/ etd/243 (Electronic theses and dissertations 243).

Halverson, C.A., 2002, 'Activity theory and distributed cognition: Or what does CSCW need to do with theories?', Computer Supported Cooperative Work 11, 243-267. https://doi.org/10.1023/A:1015298005381

Henderson, A., 2013, 10 of the worst terror attacks by extreme Christians and far-right white men, viewed 14 January 2016, from www.alternet.org/tea-party-andright/10-worst-terror-attacks-extreme-christians-and-far-right-white-men
Kagawa, F. \& Selby, D., 2014, Child-friendly schooling for peacebuilding, United Nations Children's Fund, Education Section, Programme Division, New York.

Kenny, A., 2012, Western philosophy, Clarendon Press, Oxford.

Magnuson, C.M. \& Enright, R.D., 2008, 'The church as forgiving community: An initial model', Journal of Psychology and Theology 36(2), 114-123.

Mahlomaholo, S., 2014, 'Education researchers as bricoleurs in the creation of sustainable learning environments', Perspectives in Education 32(4), 171-183.

Miedema, S. \& Ter Avest, I., 2011, 'In the flow of maximal interreligious citizenship education', Religious Education 106(4), 410-424. https://doi.org/10.1080/003440 87.2011.588116

Needleman, J., 2008, Why can't we be good?, Jeremy P. Tarcher/Penguin, New York.

Nussbaum, M.C., 2011, Creating capabilities, Belknap Press, Cambridge, MA.

Nussbaum, M.C., 2012, The new religious intolerance, Belknap Press, Cambridge, MA.

Parekh, B., 2000, 'non-ethnocentric universalism', in T. Dunne \& N.J. Wheeler (eds.), Human rights in global politics, pp. 128-159, Cambridge University Press, Cambridge.

Park, J-H., Enright, R.D., Essex, M.J., Zahn-Wexler, C. \& Klatt, J.S., 2013, 'Forgiveness intervention for female South Korean aggressive victims', Journal of Applied Developmental Psychology 34(6), 268-276, viewed 09 March 2017, from www. sciencedirect.com.nwulib.ac.za/science/article/pii/S0193397311300592?np=y\&k ey=a690b77bcff2dda1f387bac7bdea83c366e55a0edaa0ecc1c3cbf0cfa5e7524

Peck, M.S., 2006, The road less travelled, Random House, London.

Rieker, P. (ed.), 2004, Der früe Vogel fängt den Wurm! Soziales Lernen und Prävention von Rechtsextremismus und Fremdfeindlichkeit in Kindergarten und Grundschule, Deutsches Jugendinstitut Arbeitstelle R \& F, Halle.

Rodden, J., 2004, 'Forgiveness, education, public policy: The road not yet taken', Modern Age Fall, 333-341.

Roux, C., 2012, Safe spaces: Human rights education in diverse contexts, Sense Publishers, Rotterdam.

Schechtman, Z. \& Nachsol, R., 1996, 'A school-based intervention to reduce aggressive behavior in maladjusted adolescents', Journal of Applied Developmental Psychology 17(4), 535-552. https://doi.org/10.1016/S0193-3973(96)90015-5

Spaull, N., 2013, South Africa's Education Crisis: The quality of education in South Africa 1994-2011, Report commissioned by the Centre for Development and Enterprise, Johannesburg.

Stoker, H.G., 1967, Oorsprong en rigting, vol. 2, Tafelberg, Kaapstad.

Strauss, D.F.M., 2009, Philosophy: Discipline of the disciplines, Paideia Press, Grand Rapids, MA.

Taylor, N., 2007, 'Equity efficiency and the development of South African schools', in T. Townsend (ed.), International Handbook of School Effectiveness and Improvement: Review, Reflections and Reframing, vol. 17, pp. 523-540, Springer International Handbooks of Education, Dordrecht.

Taysi, E. \& Demet, V., 2015, 'Forgiveness education for Fourth Grade Students in Turkey', Child indicators Research 9(4), 1095-1115. https://doi.org/10.1007/ S.12187-015-9364-9

Tripp, P.D., 2010, What did you expect?, Crossway, Wheaton.

UNESCO, 2015, Global citizenship education. Topics and leaning objectives, UNESCO, Paris.

United States Department of State: Bureau of Democracy, Human Rights and Labor, 2014, International Religious Freedom Report for 2014, viewed 14 January 2016, from https://www.state.gov/j/drl/rls/irf/2014religiousfreedom/ index.htm\#wrapper

Van der Berg, S., 2008, 'How effective are poor schools? Poverty and education outcomes', Studies in Educational Evaluation 34, 145-154. https://doi.org/ 10.1016/j.stueduc.2008.07.005

Van der Walt, J.L., 2017, 'Some recent responses to neoliberalism and its views on education', HTS Teologiese Studies/Theological Studies 73(3), a4493. https://doi. org/10.4102/hts.v73i3.4493

Van Goor, R., Heyting, F. \& Freeke, G.-J., 2004, 'Beyond foundations: Signs of a new normativity in Philosophy of Education', Educational Theory 4(2), 173-192. https://doi.org/10.1111/j.1741-5446.2004.00013.x

Verburg, M., 2015, Herman Dooyeweerd: The life and work of a Christian Philosopher, Paideia Press, Jordan Station, Ontario, Kanada.

VSA see United States Department of State: Bureau of Democracy, Human Rights and Labor

Wahl, K., 2009, Gibt es mögliche Vorlaüfer für Rechtsextremismus und Fremdfeindlichket, die nicht bereits im Kindergarten- und Grundschulalter zeigen?, Deutsches Jugendinstitut Arbeitstelle R \& F, Halle.

Wright, R., 2009, The evolution of God, Little, Brown \& Company, New York. 